\title{
Pengentasan kemiskinan melalui pemberdayaan wirausaha dan program life skill untuk meningkatkan produktivitas kelompok UPPKS Kalipakem Baru
}

\author{
Bahri ${ }^{(i)}$ \& Widodo Prasetyo \\ Faculty of Economics, Universitas Widya Mataram, Indonesia \\ *bahri@widyamataram.ac.id
}

\begin{abstract}
This community service activity aims to increase the selling value of local products and the empowerment of entrepreneurs from members of the UPPKS Kalipakem Baru group. This activity focuses on improving life skills, productivity, marketing abilities, and online selling. The service activity delivery is done by the lecture method explaining the importance of making innovative products, improving life skills, the importance of marketing, and selling online. This activity provides training on how to create an online store and open discussions openly with participants. This activity expected that there would be an increase in the ability and expertise of participants in marketing and selling products online. This activity makes the product more known to the public and increases the number of orders so that the income of group members increases.
\end{abstract}

Abstrak Kegiatan pengabdian kepada masyarakat ini bertujuan untuk meningkatkan nilai jual produk daerah dan pemberdayaan wirausaha anggota kelompok UPPKS Kalipakem Baru. Kegiatan ini menitikberatkan kepada peningkatan life skill, produktivitas, kemampuan pemasaran, dan penjualan melalui online. Pelaksanaan pengabdian dilakukan dengan metode ceramah menjelaskan pentingnya membuat produk yang inovatif, meningkatkan kecakapan hidup, pentingnya pemasaran, dan penjualan secara online. Kegiatan ini memberikan pelatihan cara membuat toko online dan membuka diskusi secara terbuka dengan peserta. Diharapkan setelah dilakukannya pengabdian ini, adanya peningkatan kemampuan dan keahlian peserta dalam pemasaran dan penjualan produk secara online. Kegiatan ini membuat produk lebih dikenal masyarakat serta meningkatkan jumlah pesanan sehingga pendapatan anggota kelompok mengalami peningkatan.

Keywords: life skill; entrepreneurship; online shop; productivity; Bantul

\section{¿ OPEN ACCESS \\ Citation: Bahri, \& Prasetyo, W. (2020). Pengentasan kemiskinan melalui pemberdayaan wirausaha dan program life skill untuk meningkatkan produktivitas kelompok UPPKS Kalipakem Baru. Riau Journal of Empowerment, 3(1), 27-37. https://doi.org/10.31258/raje.3.1.27- $\underline{37}$ \\ Paper type: Community service}

Received: 2019-10-12 Revised: 2020-02-06 Accepted: 2020-03-04

Language: Bahasa Indonesia (id)

Funding: LPPM Universitas Widya Mataram (UWM), Yogyakarta, Indonesia

ISSN 2623-1549 (online), 2654-4520 (print)

(c) 2020 Bahri \& Widodo Prasetyo. Author(s) retain the copyright of article published in this journal, with first publication rights granted to Riau Journal of Empowerment. The article is licenced under Creative Commons Attribution 4.0 International License. This license permits unrestricted use, distribution, and reproduction in any medium, provided the original author and source are credited. 


\section{PENDAHULUAN}

Sejak Presiden Joko Widodo meluncurkan 10 paket stimulus ekonomi ditahun 2015, Usaha Mikro Kecil Menengah (UMKM) semakin bergeliat dimana Kementerian Koperasidan UMKM mencatat tiga tahun rasio wirausaha terhadap penduduk di Indonesia telah meningkat dari angka 1,56\% ditahun 2014 menjadi 3,1\% ditahun 2016, sehingga upaya untuk terus meningkatkan dan mengembangkan sektor UMKM akan dapat menyerap lebih banyak lagi tenaga kerja dan mengurangi angka pengangguran yang akhirnya akan dapat digunakan untuk pengentasan kemiskinan melalui pengembangan wirausaha dan keunggulan kompetitif serta pemberdayaan usaha skala mikro (Suci, 2017). UMKM mempunyai peran yang sangat besar dalam memajukan perekonomian Indonesia dimana UMKM berkontribusi besar dalam penyerapan tenaga kerja, yaitu menyerap lebih dari $99,45 \%$ tenaga kerja dan sumbangan terhadap PDB sekitar 30\%, selain itu UMKM juga menyerap banyak tenaga kerja Indonesia yang masih mengganggur (Susila \& Supartomo, 2014). Krisnawati (2018) menemukan teknologi digital dapat memfasilitasi pengembangan bisnis UMKM di Indonesia, dimana dengan memanfaatkan teknologi digital secara optimal UMKM dapat membangun bisnis dan meraih keuntungan yang besar dengan modal yang kecil. Teknologi digital mampu membantu UMKM memperluas jangkauan bisnisnya dari hanya di sekitar lingkungan menjadi lebih luas lagi.

Koperasi AKU Sejahtera didirikan oleh Gusti Kanjeng Ratu Mangkubumi putri pertama dari Sri Sultan Hamengkubuwono X yang berkonsentrasi pada pemodalan dan mengembangan wirausaha rakyat Yogyakarta, dimana salah satu kelompok binaan Koperasi AKU Sejahtera adalah kelompok Usaha Peningkatan Pendapatan Keluarga Sejahtera (UPPKS) Kalipakem Baru di Seloharjo, Pundong, Bantul, Daerah Istimewa Yogyakarta. Desa Seloharjo yang terletak sebelah Selatan Kantor Kecamatan Pundong yang berada di antara $110^{\circ} 12$ ' 34" - $110^{\circ}$ 31'08” Bujur Timur dan antara $7^{\circ} 44^{\prime} 04^{\prime \prime}-8^{\circ} 00^{\prime} 27^{\prime}$ 'Lintang Selatan, merupakan salah satu Desa dari 75 (tujuh puluh lima) desa di Kabupaten Bantul yang terletak di bagian Timur laut. Batas-batas wilayah Desa seloharjo: Sebelah Utara: Desa Srihardono, Desa Panjangrejo Kecamatan Pundong, Sebelah Timur: Desa Selopamioro Kecamatan Imogiri, Sebelah Selatan: Desa Girijati Kecamatan Purwosari dan Sebelah Barat: Desa Parangtritis Kecamatan Kretek. Luas wilayah Desa Seloharjo adalah 48 hektar, secara administratif terbagi menjadi 16 Pedukuhan yang meliputi 73 RT. Letak geografis Kelurahan Seloharjo sangat strategis karena dilalui oleh Jalur Wisata dari Jogja menuju obyke wisata Parangtritis, Parangkusumo dan Depok. Jalur jalan Imogiri, maka Desa Seloharjo dilalui persis (langsung) artinya wisatawan yang menuju Parangtritis dan sekitarnya akan melewati langsung Desa Seloharjo, hanya butuh berbelok sekitar $1 \mathrm{~km}$ dari jalan Parangtritis, sudah sampai sampai Kelurahan Seloharjo (Sutrisno et al., 2018).

Kelurahan Seloharjo sektor ekonominya secara umum masih berjalan lamban, belum ditata dengan baik sehingga terjadi kesenjangan yang cukup jauh, masyarakat masih banyak bersifat solo karier, kurangnya kemauan untuk berwirausaha dan susahnya mencari modal usaha. Sebenarnya untuk mengatasi dan mendukung kegiatan di kelurahan Seloharjo sudah memilik berbagai organisasi sosial diantaranya LPMD, PKK, Karang taruna, GAPOKTAN, kelompok ternak, kelompok perikanan dan kelompok UPPKS. Selain itu kelurahan Seloharjo, Kecamatan Pundong, Bantul memiliki banyak objek wisata terdiri dari Goa Jepang yang tengah berkembang menjadi destinasi "alternatif". Selain Goa Jepang, terdapat pula Goa Surocolo. Situs goa ini pernah dipergunakan Sunan Amangkurat Mas bersembunyi saat melawan Belanda. Pada situs ini terdapat dua buah sendang yang diberi nama Sendang 
Surocolo. Lokasi sendang berada di Dusun Ngreco, Desa Seloharjo, Kecamatan Pundong (Raharjana \& Kutanegara, 2019).

Terbentuknya kelompok UPPKS Kalipakem Baru secara umum diarahkan untuk mengatasi permasalahan masyarakat di bidang ekonomi, serta mendukung upaya-upaya penanggulangan kemiskinan dan kesenjangan, penciptaan kesempatan kerja dan peningkatan ekonomi masyarakat terutama kelas menengah ke bawah, serta pemanfaatan hasil pertanian untuk di olah kembali menjadi produk atau barang yang mempunyai nilai jual tinggi. Konsep kerja UPPKS Kalipakem Baru terkait dengan pembangunan masyarakat untuk meningkatkan kesejahteraan dan produktivitas anggota dan masyarakat sekitar. Menurut Krisnawati (2018) untuk meningkatkan produktivitas kelompok koperasi dan UMKM di Indonesia di dorong oleh kemajuan ilmu pengetahuan dan teknologi digital yang berdampak luas pada perbaikan dan kesejahteraan masyarakat. Dengan menguasai Iptek dapat menjadi solusi dalam menyelesaikan permasalahan masyarakat, maka perlu adanya peningkatan penguasaan, dan pemanfaatan Iptek berbasis sumber daya (Saparita et al., 2019). Oleh karena itu, pemanfaatan ilmu pengetahuan dan teknologi dapat dilakukan melalui pemberdayaan, pelatihan life skill dan inovasi produk untuk meningkatkan daya saing. Pemberdayaan memiliki makna upaya yang membangun daya masyarakat dengan mendorong, memotivasi dan membangkitkan kesadaran akan potensi yang dimiliki serta berupaya untuk mengembangkannya (Aristianto, 2018). Kesadaran masyarakat untuk ikut berpatisipasi dalam meningkatkan produktivitas dan mengembangkan potensi daerah merupakan salah satu faktor penting yang mempengarui keberhasilan program memberdayakan masyarakat (Duaja et al., 2018).

Life skill merupakan suatu kebijakan pendidikan yang berbasis masyarakat luas (broad based education) yang berorientasi pada kecakapan untuk hidup (life skill), dimana kecakapan hidup mampu dipergunakan sebagai pelatihan sebelum memasuki dunia kerja kerja (Hamid, 2012). Life skill berkaitan erat dengan kecakapan atau kemampuan yang diperlukan seseorang agar menjadi independen dalam kehidupan. Sedangkan Azizah (2015) menyatakan kecakapan hidup merupakan kecakapan yang dimiliki seseorang untuk berani menghadapi problema hidup dan kehidupan dengan dengan wajar tanpa merasa tertekan, kemudian secara proaktif dan kreatif mencari serta menemukan solusi sehingga akhirnya mampu mengatasinya. Azizah melanjutkan kecakapan hidup meliputi aspek kemampuan dan kesanggupan tercakup dalam berpikir serta aspek katerampilan tercakup dalam berpikir secara arif, inovatif dan kreatif. Inovasi dan kreativitas produk perlu dilakukan terus menerus untuk menarik perhatian pelanggan agar perusahaan tetap berdiri untuk melangsukan usahanya, dibuktikan dari hasil penelitian inovasi produk dan kreativitas produk mempunyai pengaruh positif terhadap keunggulan bersaing (Kurniasari, 2018).

Salah satu cara untuk menumbuhkan kecakapan berwirausaha di kalangan masyarakat adalah dengan meningkatkan kemampuan kewirausahaan yang berbasis teknologi. Kemampuan wirausaha di bidang teknologi yang lazim dikenal sebagai technopreneurship dimana teknopreneur merupakan gabungan antara "teknologi" dan "entrepreneur" yang secara umum digunakan untuk menjalankan industri bisnis (Kementerian Komunikasi dan Informatika, 2018). Dalam mengetahui produk-produk unggulan, masyarakat secara fleksibilitas dapat melakukan penawaran, pengiriman dan menerima informasi secara hemat dan cepat melalui sistem informasi bisnis yaitu teknologi (Kristiyanti, 2014).

Dengan semakin pentingnya e-commerce dalam dunia usaha kedepannya, maka sangat perlu dilakukan kegiatan sosialisasi, workshop ataupun pelatihan kepada pengusaha ataupun masyarakat umum lainnya. Menurut Purnawan (2016) melalui pelatihan implementasi $e$ commerce dapat menangkap peluang usaha dan dapat memberikan pengetahuan dan 
keterampilan bagi masyarakat khususnya dalam memanfaatkan teknologi agar mampu bersaing dalam bisnis global. Pelatihan e-commerce yang dilakukan Nasrullah et al. (2016) merupakan bentuk kepedulian terhadap perekonomian masyarakat diajak melek dan memanfaatkan jaringan internet untuk membangun bisnis sehingga pendapatan mereka naik serta memberikan perubahan lebih cepat terhadap masayarakat dalam konteks ekonomi dan pendidikan. Dari kegiatan pelatihan dihasilkan dalam bentuk pedirian taman baca, pemasangan pemancar signal internet dan pelatihan e-commerce untuk masyarakat bisa lebih melek pengetahuan, membangun pemasaran lebih cepat dan lebih baik.

Yulhendri dan Irawan (2015) mendefinisikan kegiatan pelatihan e-commerce tentang pembuatan toko online dapat dilakukan menggunakan aplikasi OpenCart. Saat ini untuk berhasil dalam berwirausaha, orang-orang tidak harus lagi memiliki toko secara fisik. Hanya dengan bermodalkan toko online, tidak sedikit orang yang berhasil dalam menjalankan usahanya. Bahkan skalanya bisa melebihi usaha yang dilakukan secara offline. Dengan memiliki toko online pembeli bisa dari luar negeri, sehingga dengan perkembangan internet yang pesat, setiap orang akan mudah melakukan pembelian barang yang pemesanannya dilakukan secara online. Dengan dibuatnya sebuah e-commerce sistem informasi berbasis aplikasi untuk mengenalkan produk-produk unggulan yang telah dihasilkan. E-commerce pada dasarnya merupakan membeli atau menjual produk melalui internet dan publik jaringan computer. Saputra et al. (2018) menjelaskan e-commerce adalah sarana transformasi elektronik dan teknologi pengolahan informasi digital dalam bisnis transaksi untuk menghasilkan, mengonversi, dan mendefinisikan kembali hubungan untuk penciptaan nilai di antara organisasi, dan antara organisasi dan individu. Sedangkan Meyliana (2011) menyatakan e-marketing merupakan bagian dari e-commerce yang merupakan sistem perdagangan melalui internet, yang berifat up to date, sehingga perusahaan harus memberikan layanan informasi produk yang ditawarkan secara jelas dan mudah.

Dugaan produktivitas pada anggota kelompok UPPKS Kalipakem Baru masih rendah, Konsumen yang membeli produk juga masih dari kalangan masyarakat sekitar belum bisa dijual ke luar daerah. Permasalahan yang muncul juga berkaitan dengan aspek usaha life skill anggota kelompok masih rendah, aspek produksi seperti pengembangan desain dan teknik produksi barang masih kurang, aspek pemasaran secara online masih kurang maksimal dilakukan. Benarkah demikian? Bagaimanakan bentuk-bentuk pemberdayaan, peningkatan wirausaha daerah pada anggota kelompok UPPKS Kalipakem Baru melalui inovasi produk? Bagaiman cara meningkatkan pendapatan dan produktivitas anggota kelompok UPPKS Kalipakem Baru melalui program life skill dan penerapan penjualan online shop (digital)? Inilah pokok permasalahan yang ingin diselesaikan dalam pengabdian masyarakat ini. Oleh karena itu, berangkat dari permasalahan penulis tertarik untuk melakukan pengabdian kepada masyarakat dalam bentuk penyuluhan dan tutorial untuk membuka wawasan serta menyelesaikan permasalahan anggota kelompok UPPKS Kalipakem Baru dengan adanya penguasaan tentang konsep digital, kemampuan menghasilkan produk daerah yang inovatif yang mempunyai nilai jual tinggi, kemampuan menjual secara online, meningkatkan life skill yang mendukung kegiatan anggota kelompok.

\section{METODE PENERAPAN}

Sebelum pengabdian kepada masyarakat dilaksanakan, metode pendekatan yang dilakukan dengan langkah-langkah sebagai berikut: 
1. Company visit melakukan diskusi bersama pengurus Koperasi AKU Sejahtera. Melalui kegiatan ini diperoleh informasi berkaitan dengan Anggota kelompok UPPKS yang membutuhkan pengarahan sesuai dengan tema pengabdian (Gambar 1). Setelah itu, melakukan diskusi bersama ketua koordinator anggota kelompok UPPKS Kalipakem

Bahri \& Prasetyo Baru yang berkaitan dengan permasalahan anggota kelompok, waktu pelaksanaan, dan perlengakapan yang dibutuhkan untuk kelancaran pelaksanaan pengabdian (Gambar 2).

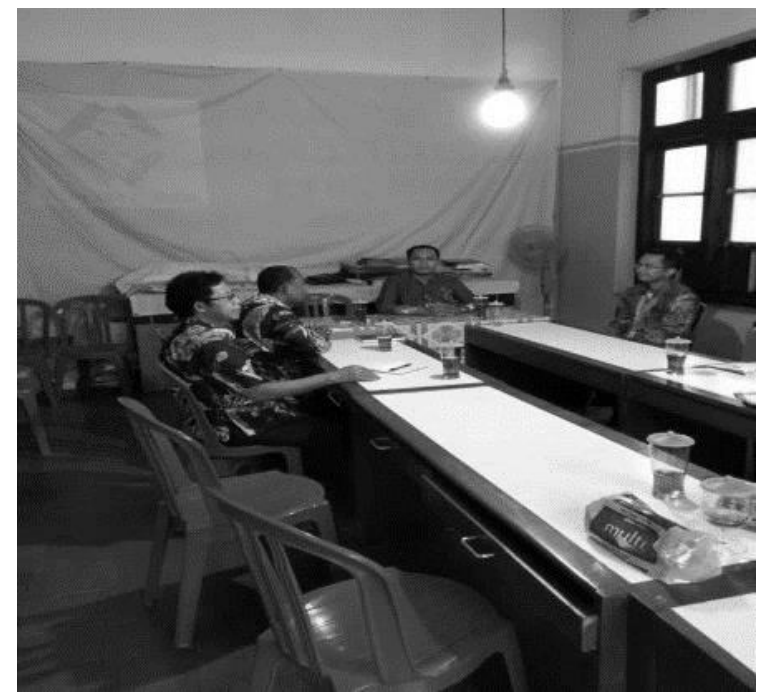

Gambar 1. Diskusi bersama pengurus Koperasi AKU Sejahtera

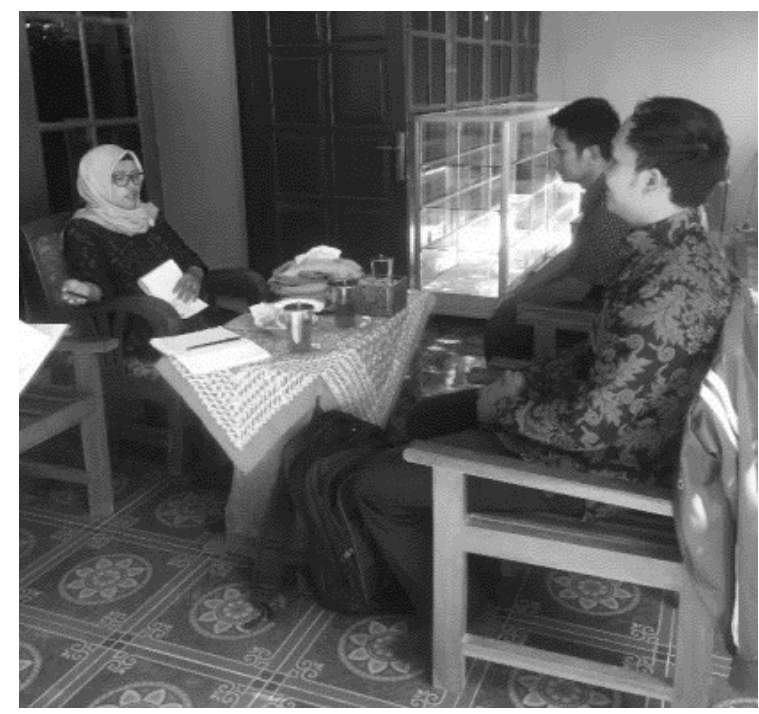

Gambar 2. Diskusi bersama Ketua Koordinator kelompok UPPKS Kalipakem Baru

2. Menyiapkan segala kebutuhan dalam pelaksanaan pengabdian termasuk pembuatan materi penyuluhan tentang bentuk-bentuk pemberdayaan usaha yang perlu dilakukan pada anggota kelompok sebagai upaya untuk pengetasan kemiskinan.

3. Menambah materi yang dapat meningkatkan pengetahun dan kemampuan anggota kelompok tentang program life skill berbasis kewirausahaan digital demi tercapainya produktivitas anggota kelompok UPPKS Kalipakem Baru.

4. Mempersiapkan alat-alat perlengkapan yang dibutuhkan dalam kegiatan pengabdian. Pelaksanaan pengabdian dilakukan dengan 3 tahapan, yaitu ceramah, diskusi dan tutorial 
pembuatan aplikasi tempat penjualan online Shopee dan mencoba menawarkan produknya secara online.

\section{Tahap Penyuluhan (Ceramah)}

Memberikan pemahaman tentang perlunya pemberdayaan usaha daerah melalui perbaikan kualitas sumber daya manusia, pengembangan dan peningkatan kualitas produk yang kreatif dan inovatif, harus memiliki keunggulan kompetitif, menggunakan teknologi atau e-commerce untuk penjualan online. Cara disampaikan dalam penyuluhan agar dapat memotivasi semua anggota kelompok yang hadir. Ibu-ibu anggota kelompok UPPKS Kalipakem Baru Soloharjo, Pundong, Bantul menjadi peserta penyuluhan. Kegiatan penyuluhan ini bertujuan untuk memberikan informasi tentang pentingnya peningkatan kualitas produk, pentingnya membuat produk yang inovatif, unik atau berbeda dengan produk lain serta perlunya melakukan penjualan secara online untuk meningkatkan pendapatan dan nilai jual produk daerah, serta meningkatkan produktivitas anggota kelompok melalui program life skill. Para anggota kelompok UPPKS Kalipakem Baru di awal penyuluh diberikan pertanyaan seputar pemahaman mereka tentang, apa perlunya pemberdayaan usaha, kenapa perlu peningkatan life skill, kenapa saat ini penting memahami aplikasi jual-beli online. Dilakukan test Tanya jawab untuk menguji sejauh mana tingkat pengetahuan peserta terhadap materi yang akan disampaikan. Diharapkan adanya peningkatan pengetahuan peserta. Untuk lebih memperdalam kembali pemahaman peserta, tim penyuluh kembali memberikan kesempatan kepada peserta untuk memberikan pertanyaan dan mendiskusikan kembali letak ketidakpengetahuan peserta, mendiskusikan permsalahan-permasalahan yang selama ini mereka alami, setelah itu tim penyulum memberikan jawaban atas pertanyaan tersebut dan memberikan solusi atas permasalahan yang dialami oleh peserta.

\section{Tahap Tutorial (Pelatihan)}

Setelah memberikan pengetahuan dari penyuluhan, kegiatan selanjutnya dilakukan tutorial atau pelatihan pembuatan akun toko online shop, metode pelaksanaanya menggunakan media smartphone. Pelatihan ini bertujuan untuk mengajarkan kepada anggota kelompok UPPKS Kalipakem Baru cara membuat aplikasi toko online, melakukan penjualan secara online agar produknya bisa dikenal dan dibeli oleh masyarakat luas. Cara menampilkan gambar produk dan konten menarik agar diminati calon konsumen. Anggota kelompok UPPKS Kalipakem Baru dibagi menjadi beberapa kelompok kecil dan tim penyuluh mengajarkan cara membuat akun toko online di aplikasi secara bertahap (step by step). Kegiatan diawali dari mendownload aplikasi, membuat akun email, mendaftar dan log in menggunaka email yang sudah dibuat ke aplikasi. Setelah masuk selanjutnya dosen menjelaskan cara menggunakan aplikasi, cara memasukkan gambar produk diaplikasi serta cara membuat konten promosi yang baik dan benar. Dosen selaku tim penyuluh juga menjelaskan cara transaksi pembayaran yaitu harus membuat rekening bank terlebih dahulu karena sistem pembayaran pada saat transaksi jualbeli online menggunakan metode transfer. Di akhir kegiatan tutorial/pelatihan setiap anggota diminta untuk menyampaikan permasalahan yang dihadapi dalam pembuatan dan penggunaan aplikasi. Setelah itu tim penyuluh mengecek hasil toko online shop yang sudah dibuat oleh setiap peserta dalam hal email registrasi, pengadaan toko online, penamaan toko online, penampilan, kesiapan dalam memasukkan produk, nomor rekening bank, konten atau katakata yang mampu menarik calon konsumen. 
HASIL DAN KETERCAPAIAN SASARAN

\section{Penyuluhan}

Bentuk-bentuk pemberdayaan usaha potensi daerah yang perlu dilakukan sebagai upaya untuk pengetasan kemiskinan dimana peserta penyuluhan adalah ibu-ibu yang bergabung menjadi anggota kelompok UPPKS Kalipakem Baru, berkumpul di rumah ibu Partini selaku ketua kelompok. Materi penyuluhan tentang pengertian, pemanfaatan dan perlunya dilakukan pemberdayaan usaha daerah, perlunya peningkatan kemampuan kehidupan (life skill), pentingnya membuat produk yang inovatif, pentingya melakukan penjulan online. Kegiatan penyuluhan dimulai dengan diskusi ringan yang berisi beberapa pertanyaan tentang inovasi, digital marketing, aplikasi online, life skill, pemberdayaan, produk-produk unggulan, hal ini perlu dilakukan untuk memancing ibu-ibu peserta untuk mau berinteraksi, menilai sejauh mana pemahaman dasar ibu-ibu peserta sebelum mendapatkan penyuluhan tentang, memahami kendala-kendala yang dihadapi peserta. Selanjutnya dilakukan pemaparan materi.

Pada saat pemaparan materi, ibu-ibu anggota peserta aktif melakukan diskusi secara langsung dengan pemateri dengan memberikan pertanyaan seputar isi materi yang disampaikan yang dikira belum dipahami. Peserta dalam hal ini anggota kelompok yang hadir setidaknya mendapatkan pengetahuan tentang perlunya inovasi produk, perlunya peningkatan kemampuan, pemberdayaan usaha, perlunya membuat akun dan toko online shop, pentingnya melakukan pemasan dan penjualan secara online untuk bisa meningkatkan pendapatan anggota, dan dengan adanya penyuluhan pengetahuan kepada masyarakat ini anggota kelompok UPPKS menjadi semakin meningkat dan produktif. Peningkatan ilmu pengetahuan ini dapat diketahui dari hasil diskusi, memberikan pertanyaan dan penilaian yang dilakukan setelah selesai memberikan materi penyuluhan. Dari hasil diskusi ulang peserta dan tim penyuluh dengan memberikan pertanyaan dimana pengetahuan anggota kelompok mengalami peningkatan. Pertanyaan diawal yang belum dipahami dan belum diketahui diakhir materi para ibu-ibu peserta mampu menjelaskan pentingnya inovasi produk, pentingya pemberdayaan usaha, pentingnya peningkatan kemampuan, pentingnya memiliki akun online shop, pentingnya memiliki toko online shop, pentingya melakukan pemasaran dan penjualan secara online. Suasana penyuluhan pemberian materi dapat terlihat pada Gambar 3.

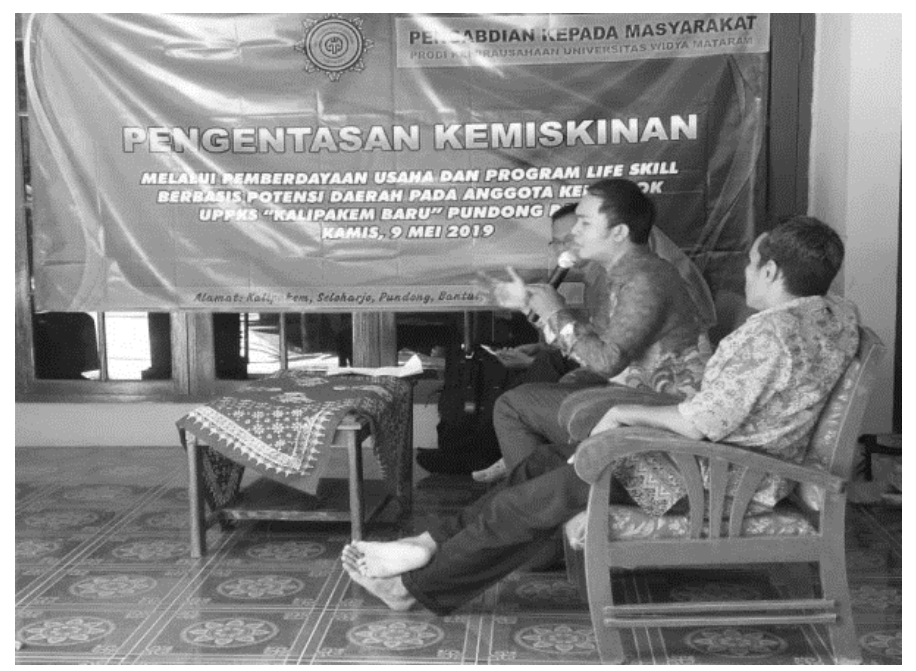

Gambar 3. Pemberian materi tentang program life skill dan inovasi produk daerah
Bahri \&

Prasetyo 


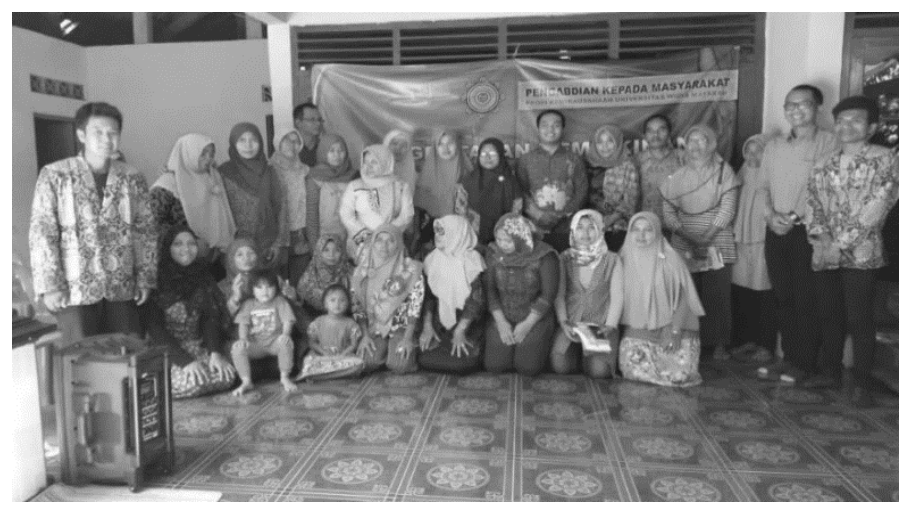

Gambar 4. Anggota kelompok UPPKS Kalipakem Baru

Anggota UPPKS Kalipakem Baru yang menjadi peserta dalam penyuluhan ini kurang lebih berjumlah 20 orang (Gambar 4). Peserta sangat antusias dan serius dalam mendengarkan materi yang disampaikan. Beberapa dari peserta juga memberikan pertanyaan kepada pemateri. Selain pemaparan materi tentang pentingnya melakukan peningkatan skill dan inovasi produk, peserta juga diberikan pelatihan (tutorial) pembuatan toko online. Pelaksanaan program tutorial ini cukup menarik, peserta sangat antusias melontarkan pertanyaan pada proses pembuatan yang tidak dimengerti.

\section{Tutorial Pembuatan Toko Online Shop}

Setelah melakukan penyuluhan dengan memberikan materi inovasi produk, pemberdayaan usaha daerah, peningkatan life skill, pentingnya digital marketing, pentingnya pemasaran dan penjalan online. Selanjutnya untuk mengatasi keluhan dan permasalahan yang dihadapi ibuibu anggota kelompok UPPKS Kalipakem Baru yaitu tentang cara membuat akun dan mendaftar toko online shop. Dalam hal ini kami memberikan pendampingan dengan membantu ibu-ibu peserta anggota kelompok dengan membuat akun dan toko online shop. Seperti terlihat dalam Gambar 5. Tahapan-tahapan yang dilakukan adalah:

1. Tahap pertama: Mempersiapkan laptop dan untuk ibu-ibu peserta bisa menyediakan smartphone yang tersambung dengan jaringan internet. Serta menyediakan nomor handphone yang digunakan untuk hergistrasi

2. Tahap kedua: Mulai pelaksanaannya, yaitu mendownload aplikasi online shop dalam hal ini yang digunakan aplikasi Shopee yang merupakan aplikasi e-commerce nomor $1 \mathrm{di}$ Indonesia. Dikutip dari halaman https://kumparan.com/kumparantech pada tanggal 7 Januari 2019 berdasarkan App Annie sebuah perusahaan analisis riset pasar aplikasi mobile, Shopee menduduki peringkat pertama sebagai aplikasi belanja online yang paling banyak diunduh. Selanjutnya dikutip dari halaman https://marketeers.com pada tanggal 9 Desember 2019 berdasarkan Riset: Shopee Jadi Platform E-Commerce Nomor Satu di Indonesia. Menurut Christin Djuarto, Direktur Shopee Indonesia selain dinobatkan sebagai aplikasi nomor satu di Indonesia, Shopee terus memperkuat posisinya menjadi destinasi berbelanja online nomor satu.

3. Tahap ketiga: Setelah selesai download, selanjutnya melakukan penginstalan dan registrasi dengan memasukkan nomor handphone, nama pengguna, nama toko online shop serta pembuatan paswood.

4. Tahap keempat: Setelah registrasi selesai, akun dan nama toko online shop sudah jadi, maka ditahap ini, kami mencoba membantu ibu-ibu peserta yang sudah punya akun untuk 
mencoba meng-upload barang yang ingin dijual ditoko nya, terus meminta memasukkan nomor rekening yang digunakan untuk bertransaksi dalam jual-beli.

5. Tahap kelima: Memberikan bimbingan cara membuat deskripsi barang (konten) yang ditawarkan dengan kata-kata yang bisa menarik konsumen untuk membeli dengan teknik

Bahri \&

Prasetyo marketing pemasaran secara online dengan menceritakan keunggulan produk yang dijual, tetapi dengan harga yang terjangkau. Sesudah memiliki akun dan toko online shop yang bisa digunakan untuk pemasaran dan penjualan.

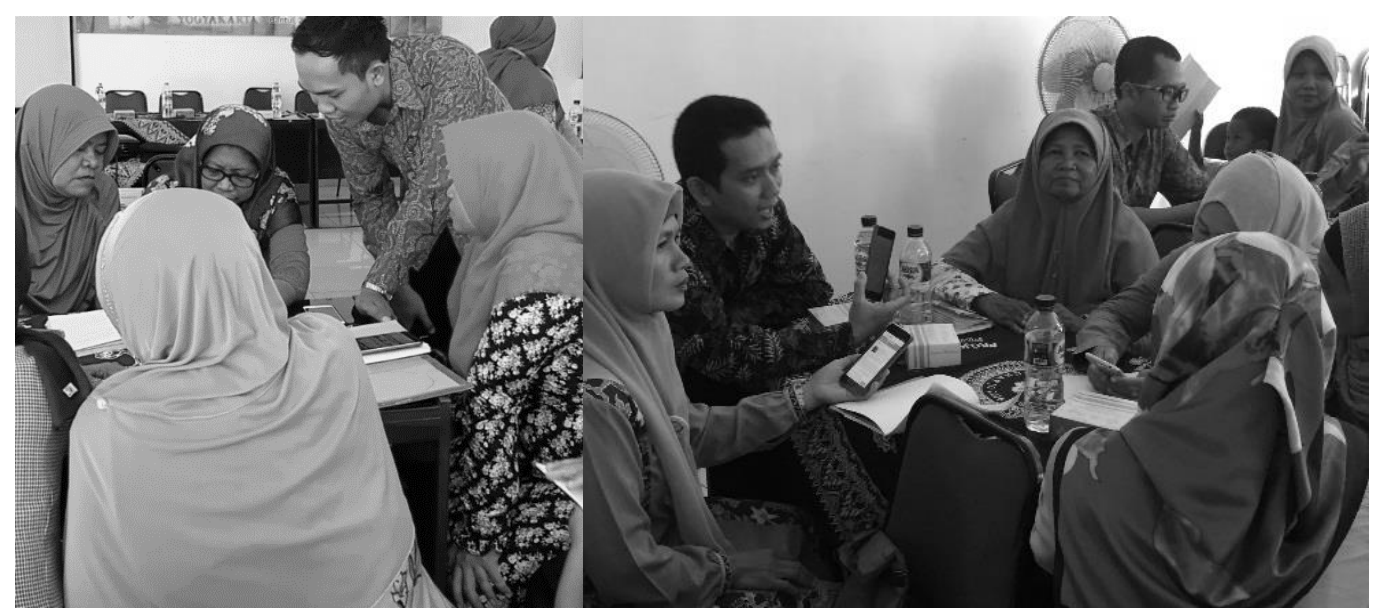

Gambar 5. Tutorial membuat akun dan toko online shop

\section{KESIMPULAN}

Kegiatan pengabdian kepada masyarakat ini dilakukan dengan memaparkan materi, diskusi dan tutorial dalam membuat akun dan toko online shop dimana dalam kegiatannya terlebih dahulu dilakukan penyuluhan untuk meningkatkan pemahaman anggota kelompok UPPKS Kalipakem Baru, tentang pengertian, pemanfaatan dan perlunya dilakukan pemberdayaan usaha daerah, perlunya peningkatan kemampuan kehidupan (life skill), pentingnya membuat produk daerah yang kreatif dan inovatif, pentingya melakukan pemasaran dan penjulan online melalui e-commerce. Kegiatan pengabdian kepada masyarakat ini mampu meningkatkan pengetahuan anggota kelompok UPPKS Kalipakem Baru dalam memahami pentingnya menciptakan produk daerah yang kreatif dan inovatif serta mempunyai nilai jual tinggi, mampu memahami pentingnya program pemberdayaan berbasis life skill dalam peningkatan produktivitas wirausaha. Setiap peserta ibu-ibu anggota kelompok UPPKS Kalipakem Baru telah memiliki toko online shop (e-commerce) dalam bentuk akun Shopee yang bisa dimanfaatkan untuk promosi dan penjualan secara online. Sehingga produk-produk yang dijual bisa dibeli oleh masyarakat luas. Implikasi dari kegiatan ini ibu-ibu anggota kelompok UPPKS Kalipakem Baru yang sudah memiliki akun Shopee diharapkan bisa digunakan untuk menjual produk-produknya sehingga berdampak pada adanya peningkatan pendapatan dan kesejahteraan semakin baik.

Untuk mewujudkan peningkatan nilai jual produk daerah, peningkatan produktivitas dan life skill anggota kelompok UPPKS Kalipakem Baru Seloharjo, Pundong, Bantul, ada beberapa rekomendasi yaitu perlu pembinaan secara berkelanjutan untuk meningkatkan kemampuan anggota kelompok dalam menghasilkan produk daerah yang kreatif dan inovatif. Masyarakat perlu diberikan pelatihan untuk meningkatkan kecakapan skill anggota kelompok dalam penggunaan toko online shop. Pemerintah daerah dan pemerintah desa perlu 
membangun sinergi dan kerjasama dengan perguruan tinggi untuk bisa memberikan pelatihan ke setiap anggota secara terus-menerus. Pemerintah desa dapat membantu menyediakan fasilitas, peningkatan kapasitas dan pasar yang mendukung pemanfaatan e-commerce dalam penjualan produk setiap anggota. Untuk itu perlu adanya program-program pemerintah desa yang mendukung kemajuan usaha-usaha setiap anggota kelompok. Selain pemerintah desa, perlu adanya dukungan ketua dusun, karang taruna atau pemuda yang lebih memiliki semangat dan kemampuan lebih besar dalam pemanfaatan teknologi, sehigga mampu membantu pemberdayaan usaha dan penjualan produk-produk daerahnya.

\section{UCAPAN TERIMA KASIH}

Terima kasih kami ucapkan kepada LPPM Universitas Widya Mataram (UWM) Yogyakarta yang telah memberikan dana dan memberi dukungan atas kegiatan pengabdian masyarakat ini. Terima kasih kepada bapak Dekan, Wakil Dekan I dan Wakil Dekan II Fakultas Ekonomi yang telah memberikan dukungan dan ijin kepada kami sehingga pengabdian ini terlaksana. Terima kasih kami ucapkan kepada pengurus Koperasi AKU Sejahtera yang telah memfasilitasi kegiatan pengabdian ini. Secara khusus kami ucapkan terima kasih kepada Ketua kelompok UPPKS Kalipakem Baru beserta anggota kelompok atas bantuan, fasilitas dan kerjasamanya. Terima kasih kepada Pak Lurah beserta jajarannya, Pendamping UPPKS, Ketua RT, RW, dan Kepala Pedukuhan Seloharjo, Pundong serta segenap masyarakat atas semua ijin sehingga kegiatan ini dapat berjalan dengan lancar.

\section{Daftar Pustaka}

1. Aristianto, A. (2018). Pemberdayaan Keluarga Lansia Melalui Usaha Ekonomi Produktif Oleh Bina Keluarga Lansia Ayah Bunda Ceria Kelurahan Tamanan Tulungagung Perspektif Ekonomi Islam (Undergraduate Thesis). Institut Agama Islam Tulungagung, Tulungagung, Indonesia.

2. Azizah, N. (2015). Manajemen Pendidikan Life Skill (Studi Kasus di Pondok Pesantren Life Skill Daarun Najaah Semarang) (Undergraduate Thesis). Universitas Islam Negeri Walisongo, Semarang, Indonesia.

3. Duaja, M.D., Buhaira, Nelyati, \& Kartika, E. (2018). Pemberdayaan masyarakat Desa Sri Agung untuk meningkatkan ketahanan pangan dengan introduksi padi hitam di pekarangan. Riau Journal of Empowerment, 1(1): 37-43. https://doi.org/10.31258/raje.1.1.5

4. Hamid. (2012). Pelaksanaan Program Life Skill Education dalam Meningkatkan Kesuksesan Mahasiswa. Jurnal Edu-Islamika, 4(2), 270-288.

5. Kementerian Komunikasi dan Informatika. (2018). Strategi Kewirausahaan Digital, Sebuah Panduan untuk UMKM, Startup, dan E-Commerce. Jakarta, Indonesia: Kementerian Komunikasi dan Informatika.

6. Krisnawati, D. (2018). Peran Perkembangan Teknologi Digital pada Strategi Pemasaran dan Jalur Distribusi UMKM di Indonesia. Jurnal Manajemen Bisnis Krisnadwipayana, 6(1), 69-74. https://doi.org/10.35137/jmbk.v6i1.175

7. Kristiyanti, M. (2014). Rancang Bangun Prototype Berbasis Web Sebagai Implementasi Praktik Wirausaha Mahasiswa di Kota Semarang. Jurnal Ekonomi dan Bisnis, 17(2), 23-40. https://doi.org/10.24914/jeb.v17i2.266

8. Kurniasari, R.D. (2018). Pengaruh Inovasi Produk, Kreativitas Produk, dan Kualitas Produk Terhadap Keunggulan Bersaing (Studi Kasus pada Produk Kerajinan Enceng Gondok “AKAR”) (Undergraduate Thesis). Universitas Negeri Yogyakarta, Yogyakarta, Indonesia.

9. Meyliana. (2011). Analisa Strategi E-Marketing dan Implementasinya pada Rental Company. Binus Business Review, 2(1), 31-51. https://doi.org/10.21512/bbr.v2i1.1109 
10. Nasrullah, D., Hidayatullah, A., \& Satria U.W.P. (2017). Pendampingan E-Commerce dan Pendidikan di Cerme Kecamatan Ngimbang Lamongan. Aksiologiya: Jurnal Pengabdian Kepada Masyarakat, 1(1), 11-17. https://doi.org/10.30651/aks.v1i1.301

11. Purnawan, I.K.A. (2016). Pelatihan Implementasi E-Commerce untuk Menangkap Peluang Usaha bagi Generasi Muda di Kelurahan Kuta. Buletin Udayana Mengabdi, 15(2), 107-111. https://ojs.unud.ac.id/index.php/jum/article/view/22568

12. Raharjana, D.T., \& Kutanegara, P.M. (2019). Pemberdayaan Masyarakat di Kawasan Cagar Budaya. Jurnal Tata Kelola Seni, 5(1), 50-65. https://doi.org/10.24821/jtks.v5i1.3145

13. Saparita, R., Hidajat, E.W, \& Apriliyadi, E.K. (2019). Pengembangan ekonomi desa penghasil kopi melalui pemanfaatan ilmu pengetahuan dan teknologi di Kabupaten Belu. Riau Journal of Empowerment, 2(2), 81-91. https://doi.org/10.31258/raje.2.2.81-91

14. Saputra, A.R., Nuryanti, B.L., \& Utama, D.H. (2018). Pengaruh Electronic Commerce Terhadap Keberhasilan Usaha Di Kawasan Tekstil Cigondewah Kota Bandung. Strategic: Jurnal Pendidikan Manajemen Bisnis, 18(2), 81-90. https://doi.org/10.17509/strategic.v18i2.17596

15. Suci, Y.R. (2017). Perkembangan UMKM (Usaha Mikro Kecil dan Menengah) di Indonesia. Jurnal Ilmiah Cano Ekonomos, 6(1), 51-58.

16. Susila, A.R., \& Supartomo, C.B. (2014). Potensi Ekonomi Daerah dan Peran UMKM dalam Usaha Penanggulangan Kemiskinan di Kabupaten Lebak. Tangerang Selatan, Indonesia: Universitas Terbuka.

17. Sutrisno, Satyarini, T.B., \& Iman, M. (2018). Perintisan Desa Wisata Berbasis Alam dan Budaya di Seloharjo, Pundong, Bantul Yogyakarta. BERDIKARI: Jurnal Inovasi dan Penerapan Ipteks, 6(1), 16-28. https://journal.umy.ac.id/index.php/berdikari/article/view/4515

18. Yulhendri, \& Irawan, B. (2015). Pelatihan E-Commerce dengan Membuat Toko Online Menggunakan Opencart di SMK Pasundan Tangerang. Jurnal Pengabdian Masyarakat AbdiMas, 2(1), 110-118. https://ejurnal.esaunggul.ac.id/index.php/ABD/article/view/1297 